\title{
The gift and the meaning-giving subject: a reading of Given Time
}

\section{Jacques de Ville}

\begin{abstract}
In this essay the relation between justice and the gift in Derrida's thinking is explored. The essay shows that an understanding of the ontological difference or the relation between Being and beings in Heidegger's thinking as well as Freud's speculations on the death drive are essential to comprehend the 'concept' or 'notion' of différance as well as the gift in Derrida's thinking. The analysis points to the complexity of Derrida's thinking in his contemplation of the relation between justice and law and the need for a broader investigation to understand what is at stake in this regard. An exploration of the gift shows that Derrida's thinking on justice is not 'relativistic' as is often assumed and that the gift can in a certain way function as a 'guide' in questions of constitutional interpretation.
\end{abstract}

'How is one to think the fact that everything that is only is insofar as it is given?'

Jean-Luc Marion

\section{Introduction}

Derrida's Given Time I. Counterfeit Money (1992a), stemming from a seminar presented for the first time in 1977-78, with its exploration of inter alia the gift and of time, stands in close relation to his thinking on justice and law. This can clearly be seen in Force of Law where Derrida (2002a, 254) describes justice in terms of a "gift without exchange, without circulation, without recognition or gratitude, without economic circularity, without calculation and without rules, without reason and without theoretical rationality, in the sense of regulating mastery". ${ }^{1}$ The exploration of the notions of time and the gift in Given Time takes place with reference inter alia to Heidegger's well-known statement in his 1962 lecture in On Time and Being (2002a), "es gibt Sein, es gibt Zeit" ('it gives Being, it gives time'; or 'there is Being, there is time') as well as Marcel's Mauss's analysis in The Gift (1990) of the gift in archaic societies. Given Time has not as yet received much attention from legal scholars. ${ }^{2}$ This is unfortunate since, as the quotation above shows, justice in Derrida's texts clearly has to be understood with reference to his analysis of the gift. Derrida's analysis of the gift furthermore relates to an issue which is of central importance for legal thinking, namely the origins of law. This issue is of course also addressed in

\footnotetext{
* University of the Western Cape, Cape Town, South Africa; jdeville@uwc.ac.za.

${ }^{1}$ See also Derrida (1994, 22-27).

2 For helpful 'non-legal' analyses of Given Time, see Bischof 2004, 354-363; Bennington 1993, 188-203; Derrida and Caputo 1997, 140-151; Horner 2001; Marrati 2005, 190-197, as well as the analysis of the 'gift section' in Derrida’s Glas (1986a, 242a-244a) by Gasché 1994, 192-198.
} 
other texts.3 Given Time nevertheless explores the question of law's origin from a unique angle which in turn makes possible a better understanding of Derrida's other 'legal' texts. As will be shown, the importance of Derrida's analysis of the gift furthermore lies in its ability to address the so-called impasse that is often said to characterise constitutional interpretation (Ackerman 2007, 1756). Given Time in addition points to the necessity of exploring the relation between the thinking of Derrida and Heidegger. Although Heidegger's thinking as well as the relation between Heidegger and Derrida are not completely unexplored in the legal context, much remains to be said in this regard. The current essay, although brief in this respect, will seek to elaborate on the complexity of the inter-relation of their thinking insofar as this ties in with the origins of law.

Given Time is a relatively long and complex text. It would be impossible to explore all the different aspects of this text within the space of a short essay. To nevertheless make an analysis of the main elements of this text possible insofar as it relates to Derrida's thinking on law and justice, the focus in this essay will primarily be on the first two chapters of Given Time. Notions that are mentioned in passing in these chapters such as sexual difference, mourning, desire, forgetting and repression, but which are essential for an understanding of the gift will be explored with reference to other texts of Derrida. The essay will start in section 2 with a brief exposition of Heidegger's evaluation of metaphysics. As Derrida notes in Positions (2002c, 8), his own thinking would not have been possible without the "attention to what Heidegger calls the difference between Being and beings, the ontico-ontological difference such as, in a way, it remains unthought by philosophy". 4 In Given Time Derrida then also specifically engages inter alia with Heidegger's thinking on Being as well as the difference between Being and beings, by contemplating that which precedes this difference, through the notions of the gift and of time.5 An outline of Mauss's The Gift will be given in section 3, specifically with reference to the way in which Mauss views the gift in terms of a circular economic exchange. This will be followed by a brief discussion of Derrida's analysis of Mauss's text. Here we will see the first signs of a development in terms of which the concept of the gift will be exceeded towards a certain ecstasy, "a jouissance of the concept to the point of overflowing" (Derrida and Roudinesco 2004, 5). In section 4, Derrida's own analysis of the gift will be enquired into in more detail. This will take place in four parts. In paragraph 4.1 Derrida's analysis of Heidegger's thinking on the es gibt and its relation to the gift and time will be enquired into with reference to On Time and Being (Heidegger, 2002a). In paragraph 4.2 an analysis of the 'notion' of sexual difference will be undertaken. As we will see, the gift, as well as justice, is closely related to sexual desire. This cannot be completely unexpected as the traditional idea of origin as well as of law and reason are implicitly tied to phallogocentric privilege - the privilege of the one, the unitary

\footnotetext{
${ }^{3}$ This includes texts of Derrida such as 'Before the Law' (1992b, 181-220), 'Force of Law: The "Mystical Foundation of Authority"' (2002a, 230-298) and 'Declarations of Independence' (2002b, 46-54).

${ }^{4}$ See also Derrida 1973, 153-154.

${ }^{5}$ It is perhaps important to note here that Derrida does not distinguish strictly between Heidegger's thinking before and after the so-called turn (Kehre). The same approach will be followed in the current essay in elaborating on Heidegger's thinking.
} 
origin, the father (Derrida 1991, 313-314). This in turn leads us to the notion of Mitsein in Heidegger's texts which is explored in paragraph 4.3 with reference to the notion of mourning. The gift's relation to pleasure beyond pleasure and thus to the 'notion' of différance is explored in paragraph 4.4. Section 5 will briefly consider the implications for law of the analysis of the gift, specifically with reference to Force of Law.

\section{Heidegger and metaphysics}

\subsection{The Question of Being}

For Heidegger, all philosophy since Plato, including its derivatives, constitutes metaphysics. Heidegger points out in this regard that metaphysics concerns itself with the question of being: ti to on (what is being?). Heidegger wants us to return to this question and to think it through in a more fundamental way. He wants to in a sense get behind the guiding question metaphysics poses and to pose a more original question, that is: What sustains and directs the guiding question of metaphysics? (Heidegger 1991, II 193) Heidegger's thinking can be said to be motivated by the completion of metaphysics or idealism brought about by Hegel's thinking of the absolute Idea as well as its consummation in Nietzsche's thinking of the will to power. Relying on the metaphor of harvesting we can say that Hegel succeeded in bringing in the first great harvest. Metaphysics now only involves the threshing of empty straw. Heidegger therefore seeks to go back to the source of metaphysics so as to, as he puts it, "come to know the field and what it is capable of yielding" (Heidegger 2005, 34). Heidegger is more specifically of the view that Western philosophy has forgotten the question of Being (das Sein). ${ }^{6}$ Although it has concerned itself with Being throughout its history, metaphysics has not as yet adequately thought Being. The question Heidegger concerns himself with is the more fundamental question (as compared to what happens in metaphysics) of the Being of beings. Being for Heidegger is not 'a being' (ein Seiende). A being can be any thing such as what we can grasp with our hands, mountains, a river, the moon, a group of people, the Japanese, Bach's fugues, Hölderlin's hymns, day, night, heat, noise, law etc. (Heidegger 2000, 81; Heidegger 1984a, 40; Heidegger 2005, 111). Why is the question of Being important? According to Heidegger, the question of Being determines the way in which we relate to the world around us. This can be explained with reference to the word 'is' in language. Even though 'is' can be said to drift about 'as the most threadbare word in language', it also sustains all our saying, Heidegger contends. We implicitly use the 'is' in every verb we employ. It is the same with all substantives and adjectives, all words and articulations of words. Even in our (silent) conduct towards beings, for example by walking in a forest or reading a book, their 'is' or Being is at stake. We also are in relation with the 'is' when we for example relate in our thinking to a thing that is no longer or not yet, and even a thing that simply is not (Heidegger 1991, IV 188-193).

\footnotetext{
${ }^{6}$ The use of the capital B is in line with the practice followed in many translations of Heidegger's texts, to distinguish 'Being' (a substantive, formed by turning the verb sein (to be) into a noun) more clearly from 'beings' or 'a being'.
} 
The question of Being is thus extremely important and it is something we already have a pre-understanding of, even though we tend never to think about it. We could say that because of the brightness of beings, the light of Being is obscured. Being in other words withdraws when it reveals itself in beings (Heidegger 1984a, 26). Our relation to Being is according to Heidegger made possible by man's essential nature prior to any philosophical undertaking, for otherwise man would not have been able to relate to himself as a being or to other beings at all (Heidegger 2005, 88). Philosophy itself, which as we saw primarily concerns itself with the question of Being (although it has done so in an inadequate way), is thus made possible by this essential nature of man. Philosophy is not simply thought up, but awakened in man through his relation with Being (Heidegger 2005, 32). As we will see in more detail below, philosophy has grasped the question of Being in different ways: Plato represented Being as Idea, Aristotle as energeia, Kant as position, Hegel as the absolute concept, Nietzsche as the will to power, but consistently as constant presence, which is what Heidegger wishes to place in question (Heidegger 2002a, 9; Heidegger 2005, 39).

\subsection{The understanding of Being in Metaphysics}

Despite the high regard in which Heidegger holds Plato and Aristotle, he regards, as we saw above, Plato as the first metaphysical thinker and views Western philosophy as having been caught up in metaphysics ever since. The early Greeks were not as yet under the sway of metaphysics (Heidegger 1991, IV 165). Plato and Aristotle nonetheless, like all philosophers after them, still contemplated Being, that is, the arche (principle) or ground of beings (Heidegger 2005, 71). What then happened with Plato's thinking? Plato thought of Being in a way different from the early Greeks. He did not think Being as such, but thought it from the perspective of and with reference to (the essence of) beings (Heidegger 1991, IV 207-211). More specifically, for Plato Being is the idea or the universal - that in which the particular thing (a being) has its subsistence and from which it proceeds. Plato's interpretation of Being as idea has according to Heidegger shaped the whole history of Western philosophy. One could say that all philosophy since Plato is 'idealism': Being is thought in the idea, the idealike and the ideal (Heidegger 1991, IV 162-164). The Christian understanding that all beings have a first cause in God as creator is similarly metaphysical (Heidegger 1991, III 7). It also proceeds by thinking Being with reference to beings. That which 'is' in the Christian understanding, is the ens creatum, that which is created by the personal Creator-God as the highest cause (Heidegger 1977, 130). Christianity in other words states that the Being of a being is that it has been created by God (Heidegger 1991, IV 88). Beings according to Christianity have been thought out rationally beforehand. As soon as the link between Creator and creation is broken in modernity (Nietzsche's 'God is dead'), this idea is adapted and man now takes the place of God, so that the rationality and calculation of man becomes the measure of everything, that is, interpreted as Being (Heidegger 2000, 207; Heidegger 1977, 148). This is the enlightenment idea of reason (Heidegger 1991, III 7). Heidegger (1991, III 51) puts this as follows as the profound insight of Nietzsche in his reflections on the will to power: 
Only what represents and secures rational thinking has a claim to the sanction of a being that is in being. The sole and highest court of appeal, in whose field of vision and speech is decided what is in being and what is not, is reason. We find in reason the most extreme pre-decision as to what Being means.

What 'is' in metaphysics, is therefore necessarily determined by a specific understanding of Being (Heidegger 1977, 117, 127-128). The understanding of Being in modernity, Heidegger ascribes in the first place to Descartes' Ego cogito, ergo sum. This statement entails that "[a]ll consciousness of things and of beings as a whole is referred back to the self-consciousness of the human subject as the unshakable ground of all certainty" (Heidegger 1991, IV 86).7 In modernity, the idea (Being) in Plato has thus become that which man posits for himself (Heidegger 1991, IV 174). Accordingly only that 'is' which is correctly thought (Heidegger 2000, 207). Reason has become synonymous with the subjectivity of the human subject, entailing 'the self-certain representing of beings in their beingness, that is, objectivity' (Heidegger 1991, III 96). All beings are furthermore turned into objects (Heidegger 1993, 251).

When Being is in the above-described ways turned into idea or 'whatness', the latter is promoted to the status of the Being of beings, to what really is or to what is most in being about beings, whereas beings are relegated to me on - that which really should not be and really is not. A disjoining in this way takes place between on and phainomenon. The idea furthermore becomes the paradeigma, the model and also the ideal (Heidegger 2000, 194-199). Heidegger (2000, 197) describes the consequences of the cleft that opens up between the idea and the imitation as follows:

Because the idea is what really is, and the idea is the prototype, all opening up of beings must be directed toward equalling the prototype, resembling the archetype, directing itself according to the idea. The truth of phusis - alètheia as the unconcealment that essentially unfolds in the emerging sway - now becomes homoiossis and mimēsis: resemblance, directedness, the correctness of seeing, the correctness of apprehending as representing.

If Being becomes an idea then there is no longer any link between beings and Being or between beings and truth (understood here as unconcealment or the happening of beings) - only between beings and idea. The foundations upon which metaphysical thinking is built, are thus not foundations at all, as they are themselves derived (and falsified) (Heidegger 1991, IV 163).

One can summarise Heidegger's diagnosis of metaphysics by saying that metaphysics does not draw a clear distinction between beings and Being. Metaphysics regards Being as the most abstract and emptiest of concepts and in no need of being determined any further. Being is overshadowed by beings (Heidegger 1991, IV 157).

\footnotetext{
${ }^{7}$ See also Heidegger 1991, IV 179 and Heidegger 1977, 129. This is not to be understood in an individualistic sense as the random opinion of an individual 'I' (Heidegger 1991, III 221).
} 
This is not because of a mistake in thinking, but because in the appearance of beings, Being withdraws, conceals itself (Heidegger 1991, IV 226-227). Being itself and consequently also the difference between Being and beings thus remains unexplored because metaphysics does not take account of the fact that there is a fundamental difference between Being and beings (Heidegger 1991, IV 195, 196). This difference between Being and beings is referred to by Heidegger as the ontological or onticontological difference. We already saw above that everywhere and continually, man stands in a relationship with Being when comporting himself towards beings. Man could thus also be said to "stand in the differentiation of beings and Being" (Heidegger 1991, IV 153). It is this differentiation which makes possible "every naming, experiencing, and conceiving of a being as such" (Heidegger 1991, IV 154). The ontological difference is thus the unknown and ungrounded ground and foundation of (the possibility of) ontology and of all metaphysics. The differentiation between Being and beings, we could also say, forms the basic structure of metaphysics even though it has remained unexamined as such (Heidegger 1991, IV 182).

\subsection{A different understanding of Being, in relation to Time}

Heidegger reflected on the question of Being in a number of ways. In Being and Time (1962) he explored the question of Being as a first step with reference to that being for whom its Being or existence is a question: man or in Heidegger's terminology: Dasein (literally: there-being). Being can furthermore be understood only when we understand time (Heidegger 2005, 88). According to Heidegger, one of the problems with the usual conception of time is that it is generally referred to in the same context as space. The reason for this approach lies in the metaphysical conception of Being in terms of beings, which appear in space and in time. This conception fails to recognise that space and time are not the same (Heidegger 2005, 84). In terms of the metaphysical concept of time, also to be found in Kant, time furthermore gives expression to permanence (Heidegger 2005, 118). This involves viewing time as a calculable sequence of nows (the present as actual now, the past as no longer now and the future as not yet now - (Heidegger 2002a, 11) and in terms of things that are present in time. This also informs the understanding of causality (Heidegger 2005, 109,113 ). One of the limitations of the conception of time in Kant (time as a mode of comportment of the human subject) is that it does not address the question of Being. It more specifically involves an implicit understanding of Being as constant presence. Heidegger points out that Kant's view of time simply involves that it occurs in man, instead of viewing time more fundamentally as "the ground of the possibility of the understanding of [B]eing" (Heidegger 2005, 88). Kant in this respect fails to investigate adequately the finitude of man, despite the fact that man stands at the centre of his enquiry in the Critique of Pure Reason (Heidegger 2005, 119). Instead Kant implicitly views man's way of being as being-present (Heidegger 2005, 134). Kant's discussion of time is nonetheless important as it tells us, as Aristotle and Augustine also do, that time is not something that can be found somewhere like a thing. Time can be found only in ourselves (Heidegger 2005, 85). To this 'vulgar' 
metaphysical concept of time, Heidegger opposes authentic temporality. He arrives at this notion of temporality through an enquiry into the way in which Dasein actually experiences time. Stated briefly, this notion of temporality according to Heidegger involves a unitary relation of Dasein to the present, the past and the future, stretched along 'ecstatically' (Heidegger 1962, 462). ${ }^{8}$ Ecstatic refers here to Dasein's being carried to or stretching toward a certain 'whither' (Kockelmans 1989, 283; Taminiaux 1994, 52). What Heidegger refers to as Dasein's ecstatico-horizonal temporality, involves awaiting (the future), retaining (having-been) and making things/beings present. These ecstases do not follow in succession upon each other as in the ordinary conception of time. The future is thus not later than the having-been and the havingbeen is not earlier than the present. As Heidegger $(1962,401)$ explains, "[t]emporality temporalizes itself as a future which makes present in the process of having been". The present or making things present in authentic temporality is dependent on an understanding of one's own having-been thrown forth, which is in turn determined by an anticipation of one's ultimate and ownmost possibility (Kockelmans 1989, 32, 257; Taminiaux 1994, 51). The future furthermore has priority in authentic temporality as the future relates Dasein to his own Being-towards-death. Authentic temporality is therefore primordially finite (Heidegger 1962, 378-379). The awareness of its own Being-towards-death places Dasein in a relation to Being and makes resolve and authentic existence possible. Heidegger refers to death in this regard as the ownmost possibility of Dasein, which is at the same time Dasein's utter impossibility (Heidegger 1962, 354, 378). The awareness of Dasein's own death thus structures temporality as it entails an anticipation of the future which determines the way in which Dasein relates to what has been and in making present.

Heidegger $(1962,246-252)$ moreover contends that Dasein is already thrown into the world and 'is' thus Being-in-the-world. This means that there is no world or reality outside of Dasein the existence of which has to be proven (as Descartes attempted) or to which one has no access (Kant's 'thing in itself'). Both these (metaphysical) approaches assume a subject that is world-less and that seeks to assure itself of a world (Heidegger 1962, 250). In this respect Heidegger's thinking is not very far removed from Hegel's critique of Kant regarding the noumenon. Things for Hegel are simply phenomena and there is no reason to go beyond the phenomena to the thingsin-themselves (Hyppolite 1974, 125). Heidegger's thinking in this regard can be better understood when we relate it to what was said above regarding temporality. According to Heidegger (1962, 429, 472), entities other than Dasein are strictly speaking non-temporal; they are nonetheless entities within-the-world that are encountered by Dasein 'in time' due to Dasein's temporality. It is because of Dasein's awareness of its own mortality that its existence is an issue for it, although it tends to hide this from itself by finding refuge in beings because of the security they seem to offer. Death is therefore for Heidegger not something that stands apart from life or beyond life, but is connected to the life of Dasein in a fundamental way. Heidegger

\footnotetext{
${ }^{8}$ Greek ecstasis = standing outside. This word is used by Heidegger "to emphasize a connotation of stretching towards or openness to" (Taminiaux 1994, 52).
} 
believes that an authentic life (as compared to the inauthentic life of the 'they' - das Man) would entail being fully aware of one's mortality:

Death is a possibility-of-Being which Dasein itself has to take over in every case. With its death, Dasein stands before itself in its ownmost potentiality-for-Being. This is a possibility in which the issue is nothing less than Dasein's Being-in-theworld. Its death is the possibility of no-longer-being-able-to-be-there (Heidegger 1962, 294).

In the above quotation we can see that the intricate relation between life and death is what for Heidegger defines Being. This comes out very clearly in another passage a few pages later in Being and Time (1962, 298): "Dasein is always dying already; that is to say, it is in a Being-towards-its-end." We see a similar kind of relation between life and death in Freud's thinking in relation to the death drive which Freud views as a "desire" of all living beings. 9 Western philosophy, it appears from the reflection of these two thinkers, has 'hidden' the relation between life and death from itself, thereby turning itself into a metaphysics of presence. This is borne out by the way in which Being is implicitly viewed by metaphysics through all its epochs:

Of what do we say and has one said from times of old: This "is"? What does one take as in being even when one has fallen away from the primordial Platonic way of perceiving? We say something is of that which we always and in advance encounter as always ready to hand; what is always present and has constant stability in this presence. What really is, is what already in advance can never be removed, what stands fast and resists any attack, survives any accident. The beingness of beings signifies permanent presence. What is thus in being is the true, the "truth" one can always and truly hold on to as what is stable and does not withdraw, on the basis of which one can gain a foothold. (Heidegger 1991, III 5960)

This notion of constant presence is for example expressed by Kant when he describes appearances in the Critique of Pure Reason: "All appearances contain the permanent (substance) as the object itself, and the transitory as its mere determination, that is, as a way in which the object exists" (Heidegger 2005, 116). Changes of appearance are in other words viewed simply as alteration and not as "rising up from nothing and disappearance into nothing" (Heidegger 2005, 124). The reason for Being taking this form in metaphysics is related to the interest of life in constantly maintaining and securing itself. This is why the true world in metaphysics was taken to be the one that is constant and unchanging rather than one that is changing and transforming (Heidegger 1991, II 61-62). What was at first experienced as 'presencing' has due to metaphysics become 'something present' (Heidegger 1984a, 50). Heidegger's discussion of chaos encountered by knowing (as compared to the commonsensical view that we encounter things or objects in an ordered way), in the context of a discussion of truth in Nietzsche, is revealing in this regard. Heidegger speaks in this

\footnotetext{
${ }^{9}$ See par 4.4 infra.
} 
respect of every living being, and especially man as "surrounded, oppressed and penetrated by chaos, the unmastered, overpowering element that tears everything away in its stream" (Heidegger 1991, III 84). Heidegger contends, in words that cannot but remind one of Freud's contemplation of the death drive, that Being (in metaphysics) entails an overcoming of this sheer dissolution and annihilation. It is however because of a denial of death as part of his life that man takes his refuge in a particular conception of Being as what is permanent and stable. Instead of viewing this chaos as on the outside whilst praxis or reason provides stability on the inside (as metaphysics does), the chaos must according to Heidegger (1991, III 88) be seen as what is inside:

Rather, the living being as praxis, that is, as the perspectival-horizonal securing of stability, is first installed in chaos as chaos. Chaos as the onrushing urge of living beings for its part makes the perspectival securing of stability necessary for the survival of the living being.

\subsection{Assessment}

Although acknowledging the necessity of Heidegger's questioning of the metaphysical tradition, Derrida's assessment thereof (suspending for a moment the necessarily heterogeneous nature of Heidegger's texts, which will be explored further below), is that it was not followed through to the end. What is called for according to Derrida is an even more rigorous thinking through of Being and of the metaphysical tradition. Heidegger's enquiry into the truth of Being, although it involves a radical questioning of the tradition, ultimately seeks in very metaphysical style a more fundamental truth and origin. Heidegger $(2005,71)$ in this respect for example describes Being as "the primary and ultimate ground of the possibility of every actual and conceivable being". Heidegger furthermore retains in traditional metaphysical style, oppositions such as in his discussion of time and of Dasein between the authentic and the inauthentic (or fallen-ness), and of the proper and the improper, in spite of having suspended all ethical evaluation (Derrida 1982, 63-64). In respect of the ontological difference, Derrida $(1973,153 ; 1982,66-67)$ asks whether the thinking of the difference between Being and beings does not still come from the metaphysical order and whether there is not a difference still more unthought than the difference between Being and beings, thereby alluding to différance. Heidegger's analysis of temporality raises a similar kind of question, that is, whether an alternative conception of time - here, authentic temporality - does not still remain within a metaphysics of presence, as any conception of time inevitably must (Derrida 1982, 63). Lastly, Heidegger's view of death as a possible impossibility of Dasein raises the question whether it does not risk inscribing death within a circular economy (Derrida 1993a, 29-30, 62-64). Viewing death and time in this way, as we will see below, has important implications for our conception of justice. Despite these reservations, Derrida's description of justice in terms of the gift and the invocation of justice in 'Force of Law', as well as his distancing of this conception from the Kantian regulative idea, is clearly indebted to Heidegger's destruction of the metaphysical understanding of Being as idea (Derrida 
2002a, 254-255). This destruction is a necessary step should one ultimately attempt to think Being in terms of the gift. Marcel Mauss's study of the gift further opens this possibility, as we will see in the discussion that follows.

\section{Mauss's The Gift}

Mauss's exploration of the gift in archaic or ancient societies understandably has a prominent place in Derrida's analysis in thinking the gift and time in a way that exceeds metaphysics. Mauss shows that gifts in these societies have a structure of circular exchange and are motivated by economic self-interest. Gifts are in other words coupled with an obligation to give (generously), an obligation to receive, and an obligation to reciprocate with interest, taking due account of prescribed time limits (Mauss 1990, 46). A failure to participate in this reciprocal exchange could have fatal consequences as it would amount to an act of war (Mauss 1990, 7). In the societies analysed, acts of destruction, giving of alms to the poor, giving of children in marriage, the invitation of others to share meals, drink and tobacco, the exchange of presents, are all forms of obligatory gifts. The exchange of gifts, according to Mauss (1990, 46, 60-61, 90) lies at the origin of law, morality and economy in modern society. Mauss specifically contends in this regard that the principle of justice in modern legal systems has taken the place of the gift - justice derives from the obligation resting upon those in primitive societies who had in abundance; they had to show generosity in giving alms on certain occasions on pain of being punished by the gods in avenging the poor, and in expectation that they would be richly rewarded by the gods should they do so (Mauss 1990, 23). This obligation furthermore relates to the belief that the gods and the dead are the true owners of things and possessions of this world (Mauss 1990, 20). This at first required destruction in sacrifice to the gods (killing of slaves, burning of precious oil, casting copper objects into the sea, and setting the houses of princes and blankets on fire), which of course also fulfilled the function of displaying power, wealth and lack of self-interest (Mauss 1990, 20, 47-48, 95). The giving of alms to the poor and of gifts to children, instead of to the gods, amounts to an evolution in society, entailing that men act in a way as representatives of the gods and the dead (Mauss 1990, 22). It is only relatively recently, Mauss furthermore contends, that a distinction has been drawn in legal systems between obligations and services that are not given freely on the one hand and gifts on the other (Mauss 1990, 61). According to Mauss, the exchange of generous gifts in these societies served and still serves the important function of preventing war and establishing peace between families, clans and tribes (Mauss 1990, 104-106). It brings about a certain degree of stability on the basis of which legal and economic systems can develop. This is an interesting conclusion, in light of Mauss's own remarks concerning the destruction of wealth (in times of peace) as a kind of gift which he equates with war (Mauss 1990, 8, 141-142 fn 141, 147 fn 166). The preference expressed for the exchange of gifts presumably lies in it being a war or defence of oneself without resort to arms (Mauss 1990, 106). Mauss concludes his analysis by arguing for a return to the notion of generous giving, calculated but not excessive, found in ancient civilizations (thus effectively a return to nature) in accordance with 
the principles of charity, social service and solidarity and a movement away from cold-hearted, utilitarian, calculating laws and actions (Mauss 1990, 83-100; Derrida 1992a, 66, 82).

Although in praise of Mauss's study and of his re-introduction of the word and category of the gift as lying at the origin of legal, economic and moral systems as compared to other authors who seek to do without it, Derrida (1992a, 26, 37, 42) is of the view that Mauss is not sufficiently concerned with his (that is, Mauss's) own observation that all the gifts he analyses are caught within a circular exchange. The same could be said of Mauss's conception of justice. An exchange of gifts, Derrida (1992a, 24, 37) comments, surely amounts to the annulment of the gift. Another important comment of Derrida on Mauss's study deserves mention here. Derrida (1992a, 25-26) questions the unity of meaning, which Mauss ascribes to the many different cultural practices, that is, that they all amount to the exchange of gifts. Derrida does not do this in order to say that these practices cannot be described as gifts, but instead to contend and ultimately to show that the word gift does not have a unitary meaning, that is, that it loses its meaning. This questioning ties in with Derrida's later comments on Mauss's description of a specific kind of gift. As we saw above, certain forms of 'gift', those involving the honour of a chief, are described by Mauss as going even beyond this still limited notion of generosity - they involve a 'madly' extravagant destruction and consumption, without limits, of all kinds of property. Derrida (1992a, 46-47) notes that Mauss has some difficulty in describing the actions of the destruction carried out here in terms of the gift, where there appear to be no giving and returning and also no desire of expecting a return. This madness of a gift forgetting itself, of dissemination without return, "threatens a priori the closed circle of exchangist rationality", Derrida (1992a, 47) notes. Mauss in other words wishes to describe the gift in terms of a system of circular exchange, but in the process of describing it, he shows that the concept of the gift exceeds this system.10 This is of course not to say that these actions which Mauss describes constitute gifts in the perfect sense. As we saw above, they can clearly also be inscribed within the system of circular exchange. Derrida (1992a, 45-48) is concerned here rather with the language Mauss uses in describing these gifts which seems to exceed his text on the gift as a system of circular exchange. Mauss, in giving us a narrative on the gift of circular exchange, is himself overtaken by the gift without exchange. We will see why this happens, also in the case of a constitution, in the discussion that follows. In his conclusion, Mauss furthermore acknowledges that the terms 'present' and 'gift' which he had been using throughout the text "are not themselves entirely exact" (Mauss 1990, 93; Derrida 1992a, 55). Derrida (1992a, 55) points out that Mauss here admits that the word 'gift' has no centre or identity; that its meaning is marked by dissemination and asymmetry.

\section{Derrida on the gift}

\footnotetext{
${ }^{10}$ See for example (Mauss 1990, 47): "In certain kinds of potlatch one must expend all that one has, keeping nothing back." "In a certain number of cases, it is not even a question of giving and returning gifts, but of destroying, so as not to give the slightest hint of desiring your gift to be reciprocated."
} 


\subsection{The gift and Heidegger's es gibt}

In order to understand Derrida's reading of Mauss, it is necessary to further analyse chapter one of Given Time where Derrida sets out the usual conception of the gift. This entails that someone (A) wants, desires, or intends to give something (B) to someone (C). As Derrida (1992a, 10-12) points out, this definition supposes a subject and a verb. It supposes, more specifically, a subject identical to itself and conscious of its identity, seeking through the gesture of the gift, to have its own identity recognised so that that identity comes back to it. This definition - the condition of possibility of the gift - points also to the impossibility of the gift, to the destruction, annulment, and annihilation of the gift. The circular economy involved in this exchange in other words destroys the gift. Some 'thing' cannot strictly speaking be a gift if it involves a relationship of circular exchange. As Derrida (1992a, 12) notes, "[f]or there to be gift, there must be no reciprocity, return, exchange, countergift or debt”. In every instance where something is given back, the gift is annulled. There can only be a gift if it does not lead to a debt, to a contract, to a circular exchange, either in consciousness or the unconscious (Derrida 1992a, 15-16). As soon as the gift appears as gift, it annuls or destructs itself, that is, even before it leads to gratitude. A gift can thus only be a gift if it does not appear as gift either to the donor or to the donee (Derrida 1992a, 13-14). As soon as someone gives with the intention to give, a process of self-congratulation and self-approval and thus circular return to self takes place. As soon as the gift gets caught up in the temporalizing synthesis, as soon as it is accepted, and even when it is refused, destruction of the gift takes place.

In metaphysics, as Derrida points out, the gift and the debt, the gift and the cycle of restitution, the gift and the loan, the gift and credit, the gift and the countergift, have been thought together as a system. Derrida seeks to depart from this tradition by pointing to that in the tradition which posits that there can only be gift if this does not involve return, if it interrupts the system and the symbol. This requires a gift-event that would not be caught up within a system of economic exchange. In describing this impossible gift-event, Derrida notes that it would not be sufficient for the gift to be forgotten by the donor and the donee only consciously and still be kept in the memory of the unconscious. The latter would simply entail a displacing - not an annulling or destruction (Derrida 1992a, 16). The gift would have to involve an absolute forgetting and an absolute unbinding as distinguished from repression or displacement to the unconscious. This forgetting would involve an instant that no longer belongs to the economy of time (Derrida 1992a, 17). ${ }^{11}$ It may appear strange to refer to the gift in terms of repression. Why would one want to suppress the giving of a gift? At this

\footnotetext{
${ }^{11}$ Law has an essential relation to time, as has been recognised by a number of legal scholars in recent times (see inter alia Rubenfeld 1998, 2001, Douzinas and Warrington 1994, 211-241; Douzinas 2007, 34-50; Cornell 1992, 116-154; Van der Walt 2005, 191-231; Fitzpatrick 2001, 84-90). As the analysis that follows will indirectly seek to show, this law-time couple and the circularity of economic exchange which it necessarily entails, are nevertheless unlikely to be interrupted or exceeded when one seeks to think of time in terms of an Oedipal past, a time of reconciliation, a time of repetition, a diachronic relation between the actual Other and the system, or as an extension over time.
} 
point Derrida is however no longer simply concerned with the giving of gifts in the ordinary sense, that is, someone giving something to someone other. He is engaging with the Heideggerian phrases es gibt Sein, es gibt Zeit. Through these phrases Heidegger, in On Time and Being (2002a), attempts to speak about time and Being, which as we already saw above are not present beings, in a non-propositional manner, that is, without referring to them as present-being/being-present and without speaking of them in terms of a subject-predicate relation (Derrida 1992a, 20). Both Heidegger and Derrida can in other words be said to attempt to think Being and time as made possible or 'given' by 'something' else: Ereignis (event). ${ }^{12}$

In his exploration of the es gibt in Given Time, Derrida (1992a, 22) specifically focuses on the notion of 'play' which is mentioned by Heidegger in his discussion of time in On Time and Being. ${ }^{13}$ Heidegger is contemplating here the es (it) of es gibt. He asks what the source is of Being that is sent to man in presence, or the becomingpresence of Being. According to Heidegger, and this ties in with what was said above concerning temporality in Being and Time, not only the present presences, but also what has been insofar as it still concerns us and what comes towards us from the future as it already concerns us. We can in other words say that a giving of presencing prevails in the present, the past and the future. This giving, Heidegger contends, reaches us because it is in itself a reaching. Heidegger (2002a, 13) sees a reciprocal relation here between the past, present and future which he expresses as follows:

Approaching, being not yet present, at the same time gives and brings about what is no longer present, the past, and conversely what has been offers future to itself. The reciprocal relation of both at the same time gives and brings about the present. We say "at the same time," and thus ascribe a time character to the mutual giving to one another of future, past and present, that is, to their own unity.

Heidegger then asks about the source of the unity of this three-dimensionality of what he refers to as true time. The unity of time's three dimensions, Heidegger (2002a, 15) concludes, "consists in the interplay of each toward each". This interplay of the three dimensions amounts to a fourth dimension of time. A fourth dimension of time thus keeps together the dimensions of the past, present, and future. It is this dimension that Heidegger refers to as the play of the es gibt and as Ereignis. The latter does not simply belong to time or to Being, but gives Being and time. This fourth dimension of

\footnotetext{
${ }^{12}$ As Derrida $(1992,19)$ indicates, Ereignis is a difficult word to translate. It is usually translated as event. However, as Krell points out in Heidegger $(1993,396)$, in introducing 'The Way to Language', Ereignis in Heidegger's texts is used in a special sense, related to the Latin proprius or own-ness (see also Heidegger 1993, 415-417). Krell therefore translates Ereignis as propriation (In Identity and Difference (2002b) and On Time and Being (2002a) it is translated by Stambaugh as Appropriation). Ereignis is furthermore closely related to Heidegger's thinking on death which is in turn viewed as the most proper possibility of Dasein; see Heidegger 1962, 294; and Heidegger 1993, 417. Ereignis could be said to draw Dasein into its own; into its mortal becoming in other words; see Sheehan 1998, 315.

${ }^{13}$ In other texts Derrida has indicated how the es gibt can be thought of in terms of a promise that makes language possible, and therefore as 'preceding' the 'is' which Heidegger has shown is a characteristic of all language as well as the 'what is' question of philosophy; see Derrida 1989a, 146-148; Derrida 1989b, 129-136 fn 5; Derrida 1979, 111; Derrida 1992b, 302. Thinking of the es gibt in terms of a promise of course ties in closely with Heidegger's thinking on the relation between language, Being and Ereignis.
} 
time, Derrida (1992a, 22) notes, is not a figure, but is a reference to "the thing itself". "This thing itself of time", he furthermore comments, "implies the play of the four and the play of the gift".

Heidegger's On Time and Being thus appears to make possible a thinking of the gift in the strict sense indicated above: a gift which does not involve the giving of some thing by some one (a subject) to an other (subject). At the same time this traditional definition of the gift could be employed if we hear something else in the words 'one', 'thing' and 'other' (Derrida 1992a, 11-12). In the giving of the es gibt, as Derrida (1992a, 20) points out, the es (it) is not a thing; it also entails a giving "without giving anything and without anyone giving anything - nothing but Being and time (which are nothing)". The last phrase in parenthesis is to be understood within the context of Heidegger's analysis in On Time and Being which shows that time in itself is nothing temporal; it is also not a thing, and therefore in a certain sense, nothing. Time also does not properly belong to anyone (Derrida 1992a, 28). Nothing however appears which does not need time or take time. Time is in other words the condition of possibility of phenomenality (Derrida 1992a, 6). We could say that time, as determined by the revolution of the sun, day-time, makes phenomena appear. Similarly Being is not something, a thing or a being-present/present-being. This is why one cannot say 'time is' or 'Being is', but only es gibt Sein and es gibt Zeit (Derrida 1992a, 20). If the gift, rigorously thought, entails exactly this - the giving of nothing that is and that appears as such, then time is what should be given as gift. In the words of Derrida (1992a, 29), "[w] hat there is to give, uniquely, would be called time". This also explains the first part of the title, Given Time. We could say regarding time and also regarding the gift that each of them "is what it is without being (it)" (Derrida 1992a, 28). Neither time nor the gift therefore exists as such. Nevertheless, there is gift and there is time.

Derrida (1992a, 21-22), however, points out that Heidegger's thinking in On Time and Being is clearly ordered by a desire for the proper. On Time and Being all the same opens the way to a thinking of the gift which, although not completely unrelated to the proper, exceeds the proper and reciprocation. Such a reading is made possible by thinking of the gift as exceeding economy. This furthermore allows for a thinking of Ereignis in terms of ex-appropriation or appropriation caught in a double bind, which would exceed the Heideggerian understanding thereof as propriation (Derrida 1995a, 270, 321). Without a re-thinking of the notion of the gift and of Ereignis, the es gibt in On Time and Being risks being understood in terms of oikonomia (the home, property, nomos) (Derrida 2002c, 48). Thinking of the event in terms of a gift beyond exchange would conversely allow for the gift to be thought as opening the 'history of Being' (which Heidegger (1991, III 179) defines as the history of the transformation and the devastation of Being's ungrounded truth) without belonging to it. ${ }^{14}$

\subsection{The gift and sexual difference}

\footnotetext{
${ }^{14}$ See also Derrida 1986a, 242a and Gasché 1994, 194-198.
} 
As we saw above, Heidegger's contention is that Western philosophical thinking has forgotten the question of Being. This is a question that was first posed by the early Greeks (Heidegger 1962, 2; Heidegger 1993, IV 193; Derrida 1992a, 18). We also saw that a certain thinking of forgetting plays an important role in Derrida's analysis of the gift. The forgetting that Derrida refers to is undoubtedly tied to Heidegger's notion of forgetting, but it also goes beyond a forgetting of Being; it is said to involve an absolute forgetting. For Heidegger, the forgetting of Being is not a psychological or psycho-analytical category. Absolute forgetting, as Derrida refers to it and as we will see shortly, is indeed related to psychoanalytic repression, but at the same time exceeds it. Forgetting in this sense is closely related to Derrida's thinking on time. In closely associating forgetting and the gift, Derrida seeks to go not only beyond the Heideggerian notion of a forgetting of Being, but also beyond the psychoanalytical idea of repression or the unconscious (Derrida, 1992a, 16-18, 23). The radical forgetting that Derrida is referring to here is first of all required of the donor(s), whether individual or collective. Derrida (1992a, 23) stresses the fact that even the intention to give on the part of the donor, already suffices to annul the gift:

The simple intention to give, insofar as it carries the intentional meaning of the gift, suffices to make a return payment to oneself. The simple consciousness of the gift right away sends itself back the gratifying image of goodness or generosity, of the giving-being who, knowing itself to be such, recognizes itself in a circular, specular fashion, in a sort of auto-recognition, self-approval, and narcissistic gratitude.

The above happens immediately and automatically when a subject or subjects are involved. A gift cannot therefore come about between two subjects exchanging objects, things or symbols (Derrida 1992a, 24). Heidegger's thinking in On Time and Being is for this reason of great importance in attempting to think the gift. As we saw above it seeks to go back beyond a construction of Being in terms of subjectivity and objectivity (Derrida 1992a, 24). To understand what is at stake in the notion of absolute forgetting, a number of other texts of Derrida on Heidegger and on the gift need to be briefly referred to. Derrida's invocation in Given Time of numerous psychoanalytic notions, such as the unconscious, desire (beyond desire), repression, forgetting, mourning and sexual difference as well as their relation to the gift can be understood only with reference to these texts.

In Women in the Beehive Derrida (2005a, 150) is asked a question relating to an earlier remark of his concerning the relation between sexual difference and the impossible idea of the gift (Derrida 1988, 172). It is important to note that sexual difference, as Derrida uses this concept, does not refer to a separation of the traditional two sexes as in Hegel where "[i]n each sex the organic individuals form a totality" and where sexual difference entails a hierarchical opposition of male activity/female passivity (Derrida 1986a, 110a, 112a-113a). Sexual difference, in Derrida's texts, entails a sexuality which is "completely out of the frame, totally aleatory to what we are familiar with in the term 'sexuality" (Derrida 2005a, 151). 
Sexual difference, which Derrida associates at this juncture with the gift, in other words goes beyond sexual duality (Derrida 2005a, 151; Derrida 1979, 121). Derrida relies here on his reading of Heidegger's Being and Time (1962) in 'Geschlecht: Sexual Difference, Ontological Difference' (1991).15 In this essay Derrida (1991, 382) mentions the seeming silence about sex in Heidegger's texts. Dasein in Being and Time, and therefore also the meaning of Being, appear to bear no sexual mark. Derrida however refers to a lecture in 1928 at Marburg University where Heidegger explained the need to conceive of Dasein as sexually neuter, that is, as belonging to neither of the two sexes (Derrida 1991, 385; Heidegger 1984b, 136). It is interesting to note, Derrida (1991, 386) comments, that Heidegger, in Being and Time (1927), makes no mention of the asexuality (Geschlechtslosigkeit) of Dasein, only Dasein's neutrality, yet in the Marburg course, which was meant to clear up the many misunderstandings in the reception of Being and Time, this is one of the first traits he mentions. Derrida notes the strangeness of this observation or clarification, seeing that it appears commonsensical that if Dasein is neuter, it does not belong to one of the sexes. How should this observation regarding the neutrality as to sexual difference therefore be understood? Rather than simply understand this as a subtraction or negativity in characterising Dasein, Derrida notes with reference to Heidegger's comments that this characterisation should be understood as a positivity, a richness, a code or a power of Dasein (Derrida 1991, 387; Heidegger 1984b, 136137). The sexual neutrality of Dasein does not therefore point to the absence of sexuality; not to the absence hence of libido, instinct or desire, but simply to the absence of any mark belonging to one of the two sexes (Derrida 1991, 387; Derrida 1988,180 ). The meaning of the neutrality as to sexual difference that Heidegger refers to could thus be summarised as follows:

If Dasein as such belongs to neither of the two sexes, that does not mean that its being is deprived of sex. On the contrary: here one must think of a predifferential, or rather a predual, sexuality - which does not necessarily mean unitary, homogeneous, or undifferentiated.... [I]t would indeed be a matter here of the positive and powerful source of every possible "sexuality" (Derrida 1991, 387-388).

This asexuality is thus also not to be understood as an allusion to some primitive or subsequent bi-sexuality (Derrida 1988, 180). Derrida could consequently be said to read Heidegger as saying that 'sexuality' is an essential part of the structure of Dasein and therefore influences, or rather, necessarily determines the meaning of Being and the ontological difference (Derrida 1991, 390, 393).16 This more originary structure of ipseity (Selbstheid) understood in terms of Dasein's sexuality furthermore makes possible the emergence of the ego and of the you (Derrida 1991, 391). ${ }^{17}$ As with sexual difference, the word 'sexuality' should not be understood here in its usual sense. Derrida notes that Heidegger explicitly relates sexuality to the internal possibility which Dasein harbours within itself of dispersal, dissemination, destruction,

\footnotetext{
15 See Kamuf (2001) for an excellent analysis.

${ }^{16}$ See also Heidegger (1991, I 194).

${ }^{17}$ See similarly Derrida (1993a, 61) on originary mourning.
} 
shattering, and fragmentation (Derrida 1991, 391-392; Heidegger 1984b, 137-138). This dissemination is thus not an ontic structure, but an originary structure of Dasein that affects it with lack-of-binding. The analysis of Dasein that is at stake here also necessarily affects the meaning of Being as this originary dissemination belongs to the Being of Dasein (Derrida 1991, 393). This 'theme' of dissemination in Dasein's relation to objects and itself is already to be found in Being and Time (Heidegger 1962, 439-444). Although Heidegger sometimes refers to the dispersion of Dasein as a mode of inauthenticity (Uneigentlichkeit) or as the falling of Dasein in its everydaybeing, this is not always the case. At times, it is used to describe the general structure of Dasein (Derrida 1991, 399, 400). Inauthenticity is furthermore not a moralizing critique, a philosophy of culture, a dogmatic religious account of the fall from an original condition or a corruption of human nature (Derrida 1991, 400; Minkkinen 1999, $59 \mathrm{n}$ 36). Nevertheless, Heidegger does sometimes make use of the distinction between the authentic/proper and the inauthentic/improper to impose a hierarchical opposition, the very typical metaphysical nature of which cannot be denied (Derrida 1982, 63-64). In exploring further the structure of Dasein in Being and Time, Derrida notes that its dispersion makes Dasein occur as Erstreckung or Ausdehnung (stretching, expansion, elongation, prolongation) which as Derrida (1991, 394) points out -

names a spacing which, "before" the determination of space as extensio, comes to extend or stretch out being-there, the there of Being, between birth and death. As an essential dimension of Dasein, the Erstreckung opens up the between that links it at once to its birth and to its death, the movement of suspense by which it itself tends and extends itself between birth and death, these two receiving their meaning only from that intervallic movement. Dasein affects itself with this movement, and that auto-affection belongs to the ontological structure of its historicity. ${ }^{18}$

This pre-spatial dispersion of Dasein is manifested inter alia in language (Derrida 1991, 395; Heidegger 1984b, 138). In writing, which as we know has been 'repressed' by metaphysics because of its relation to the trace, this dispersion is for example expressed by the spacing of signs, punctuation, intervals, and differences between signs (Derrida 1976, 68, 167; Derrida 2002c, 23). All graphemes, Derrida $(1976,69)$ notes, are of a testamentary essence. Dasein's originary dispersion is furthermore closely linked to its thrown-ness (Geworfenheit). Thrown-ness, as Derrida $(1991,396)$ points out, has to be understood as preceding any project on the part of Dasein, the categories of passivity and activity which are closely related to the subject, images of the fall, whether Platonic or Christian, as well as of spatiality. The originary spatiality of Dasein thus depends on the throw. The (disseminal) thrown-ness of Dasein, as Heidegger points out, becomes particularly manifest in Dasein's Being-with (Mitsein) other Dasein, a notion, as Derrida notes, which also has sexual connotations (Heidegger 1984b, 139; Derrida 1991, 396, 401). The Mitsein and thrown-ness of

\footnotetext{
${ }^{18}$ See also Heidegger (1962, 424-429).
} 
Dasein could also be thought in relation to the Levinasian notion of the hostage (Derrida 1995a, 275-6, 283-4; Derrida 1999a, 55-57; Derrida 1993a, 61-62, 65-66).

\subsection{The gift and mourning}

The notion of Mitsein and its relation to Derrida's thinking can be better understood when taking account of his reflections on mourning. ${ }^{19}$ Derrida, following the analyses of Nicolas Abraham and Maria Torok (1994, 125-138), draws a distinction in a number of his texts between the work of mourning on the one hand and mourning which does not take place in the normal way or what could also be referred to as the non-work or the play of the gift on the other hand. ${ }^{20}$ The relevance of mourning lies in the role it plays in the structure and formation of the self (Krell 2000, 16; Derrida 1989a, 33-34). Briefly stated, the work of mourning or normal mourning according to Freud would entail the total digestion, assimilation, introjection and idealisation of the dead person in order to withdraw the libidinal investment in that person and to re-constitute the self. Although introjection is inevitable, being a desire for presence as counter-reaction to identification with the dead, total assimilation is strictly speaking impossible (Derrida 1999b, 235). This is because death makes clear the distinction between self and other, seeing that it requires of a self to bear some one outside of them that absolutely exceeds them within them (Derrida 1989a, 33-34; Derrida 2001a, 159). 'Abnormal' mourning on the other hand would involve the incorporation of the dead person in a crypt in the ego (Derrida 1986b, xvi-xvii). The dead person would thus not be internalised or become a part of us as in the work of mourning, but would nonetheless be taken inside the self, inhabiting the ego as a stranger, a persecutor, having been granted absolute hospitality and left in his/her alterity. The 'living-dead' person can in this way haunt our body, look at us and speak through us, become our law, the law, stronger and more forceful than us (Derrida 2001a, 160). ${ }^{21}$ Even before their death, we already carry those we love, our friends, in

\footnotetext{
${ }^{19}$ See also Derrida 1992a, 36. Attempts to translate the thinking of Derrida and Freud on mourning into a general approach to law or to apply it to a specific area of law have been undertaken elsewhere (eg Cornell 1992, 72-81 and Barnard 2006). The present account differs in various respects from these. Derrida's exploration of friendship and of telepathy could also be relied on in exploring the notion of Mitsein; see Derrida 1997 and Derrida 2007, 226-261.

${ }^{20}$ See inter alia Derrida 2001a; Derrida 1992a, 36; Derrida 1988, 57-59; Derrida 1989a, 3-43; Derrida 1995a, 320-322; Derrida 1986b, xvi.

${ }^{21}$ Within the notion of mourning a further distinction has to be drawn, following Abraham and Torok, between "the foreigner incorporated in the crypt of the Self" as described in the text above and "the ghost that comes haunting out of the Unconscious of the other" (Derrida 1986b, 118-119 fn. 21; Abraham and Torok 1994, 140141 fn. 1, 171-205). This 'ghost' or 'phantom' also has a place in the unconscious, but "is not an effect of repression 'belonging' to the subject he comes to haunt with all kinds of ventriloquism; he is rather 'proper' to a parental unconscious". The ghost coming back to haunt is therefore not a return of the repressed (Derrida 1986b, 118-119 fn. 21; Derrida 1988, 59). Derrida relies on both of these structures in his extension of the notion of mourning to the field of the political. This can for example be seen in his discussion of the consequences of the encounter in Baudelaire's Counterfeit Money of the two friends with a beggar (or at least with the beggar insofar as he represents a purely receptive, expending and consuming agency within this particular culture) (Derrida 1992a, 134-145). The beggar could be said to function here as a 'hetero-cryptic ghost' (Derrida 1986b, xxxi). As Derrida (1992a, 138) notes, the poor, "[a]s marginal people excluded from the process of production and circulation of wealth... come to represent the gods or the dead. They occupy the place of the dead man or the spirit, the return of the ghost, that is, of an always imminent threat."
} 
us outside us in anticipating their death, which constitutes the self and the relation to the self (Derrida 1989a, 28-29):

Even before the death of the other, the inscription in me of her or his mortality constitutes me. I mourn therefore I am, I am - dead with the death of the other, my relation to myself is first of all plunged into mourning, a mourning that is moreover impossible. This is what I call ex-appropriation, appropriation caught in a double bind: I must and I must not take the other into myself; mourning is an unfaithful fidelity if it succeeds in interiorizing the other ideally in me, that is, in not respecting his or his infinite exteriority (Derrida 1995a, 321).

In Given Time as well as in other texts, Derrida seeks to extend the structure of mourning, noting that all work is a work of mourning, that is, we are always attempting to reappropriate ourselves as a reaction to our thrown-ness or loss of autonomy (Derrida 1986a, 86b; Derrida 2001a, 161). This motivates his call for a mourning of mourning or an end of mourning work, a beyond of the mourning principle (Derrida 1995a, 48-52; Derrida and Dufourmantelle 2000, 111-119). This is not the same as the successful completion of mourning, but the giving of affirmation "to an other end", which Derrida (1995a, 52) brings into relation with Freud's speculation on the death drive in Beyond the Pleasure Principle. If we think of mourning in terms of a certain being-with others, it is possible to attain some insight into Mitsein. Mitsein in Derrida's reading, as the discussion of mourning suggests, does not refer simply to a peaceful togetherness or 'reconciliation' between self and other as might be thought. Through a doubling, the boundaries between self and other are breached to the 'point' of dissolution of the self. ${ }^{22}$ In extending the notions of Mitsein and mourning to law, extreme caution is furthermore advised. Mitsein which could be another 'name' for justice can hardly be viewed simply as a reference to the (reconciliation of the) interests of the two or more parties to a legal dispute. As a number of Derrida's texts make clear, the position analogous to the I, the self or the subject as described above is that of a 'we', for example a people, nation or community (a collective subject) who relies on the law in general in an attempt to protect or safeguard themselves in their own interest from their 'destruction' or from absolute hospitality (Derrida 1992c, 9-10; Derrida 2002a, 230-298; Derrida 2005b; Derrida and Dufourmantelle 2000; Derrida 1994, 83). The self-destruction that is at stake here would be equivalent to Mitsein and also to the gift. A similar possibility of self-destruction is at stake in the case of a sexual bond and the human race (Derrida 1986a, 123a-124a; Derrida 2007, 387-409).

\subsection{The gift and différance}

The Heideggerian notions of a stretching-along between birth and death, of Mitsein, of thrown-ness, and of the gift are invoked by Derrida to contend, as he does

\footnotetext{
${ }^{22}$ This is also suggested by a number of other texts of Derrida (1994, xviii-xix, 154, 162; 1993b; 1998a, 63-65; 1976, 184-192; 1993a, 61-62, 65-66), where he deals more exclusively with being-with, and where mourning is also often referred to.
} 
elsewhere, that death is a part of life, although in a different way than Heidegger does. This becomes clear from a reading of Derrida's To Speculate - On Freud which involves a further engagement, through Freud's Beyond the Pleasure Principle (2001b, 3-64), ${ }^{23}$ with Heidegger's existential analytic of Dasein, although this time not with reference only to Dasein as providing privileged access to Being, but with reference to all beings (every organism, corpus, movement, organisation), and their 'relation' to a certain sexuality and death (Derrida 1987, 328, 347, 356). ${ }^{24}$ Derrida shows here in his reading of Freud the link between the death drive and 'sexual' desire. The primary process, death drive, absolute pleasure, or what Derrida also refers to as un-binding or final orgasm, entails a "desire" to return to the inorganic state and thus to an absolute past that is no longer a past present (Derrida 1987, 397). Every organism could be said to have a 'relation' with this desire. This is however more specifically a 'relation without relation' or, as we will see below, a differantial relation, because this desire or at least the trace thereof becomes effaced in its appearing (Derrida 1973, 156). Absolute desire or the secret of enjoyment, Derrida notes within the context of the Hegelian discussion of desire between the two sexes, has to "sacrifice[] itself, immolate[] itself to itself, say on the altar of enjoyment, in order not to destroy (itself), itself and the other, one in the other, one for the other" (Derrida 1986a, 123a-124a). Absolute desire would in other words amount to the annihilation of self in the enjoyment of the other and of the self by the other, death coinciding with the act of copulation (Derrida 1986a, 123a; Freud 2001a, 198; Freud 2001c, 47). A similar kind of incorporation and self-destruction appears to be at stake here as in the case of 'abnormal' mourning described above; a death drive thus 'shared' by all organisms, the law of sharing or partition [partage], the law of the gift (Derrida 1992a, 6; Derrida 2005b, 42-62). The 'relation' of every organism to selfdestruction or what Derrida elsewhere calls autoimmunity, can also, as noted above, be extended beyond auto-eroticism (Derrida 1976, 152-157, 179) and the sexual bond (Derrida 1976, 155) to a community (Derrida 1998a, 51), a nation (Derrida 2002a, 269-270; Derrida 2005b) and the human race (Derrida 2007, 387-409).

The movement of binding or striction described above can be understood with reference to the 'notion' of différance. Différance does not, as is the case with the ontological difference, refer to the distinction between Being and beings, but to the difference between the gift or self-destruction on the one hand and economy, law, politics, reason, meaning, experience, science, knowledge and philosophy which are in time, on the other (Derrida 1992a, 30). Différance, in other words, structures the relation between the desire for presence (which we also find in Heidegger's analysis of Being) and the desire for absolute pleasure, which remains continuously deferred. Différance could thus be said to be 'situated' between Being/beings and an other which is not 'their' other (Derrida 1995c, 104). In the current context, différance refers to absolute pleasure, the death drive, the gift beyond exchange, the putting in play or to fire of all, which must nonetheless, in order to make possible an economy of

\footnotetext{
${ }^{23}$ This is not an isolated engagement with this text of Freud. Derrida comes back to it in a number of other texts, eg in Derrida 2001b, 246-291; 1998b; 1995b.

${ }^{24} \mathrm{I}$ have explored this in more detail elsewhere and will therefore only give a very brief summary here.
} 
self-relation and a dialectic of meaning, engage in a constriction or binding, resulting in the domestic hearth (Derrida 1987, 338-409; Derrida 1986a, 242a; Freud 2001d, $90 \mathrm{fn} 1)$. As soon as there is, as Derrida $(1987,66)$ points out, there is différance. 'Prior' to this stricture of the for-(it)self, although one is no longer reckoning with time here but with an absolute past or the trace, one can speak of a pure play of difference, of a difference without subject, of indifference, of a seminal effusion without return (Derrida 1976, 66; Derrida 1986a, 239a-241a). One can also not speak of the space, locus or region of the gift, but rather, as we saw above, of spacing. Spacing is referred to by Aristotle as 'ama', the 'together of time and space', which allows for what Derrida refers to as the "becoming-space of time and the becomingtime of space" or what could also be referred to as the difference between time and space, to appear or to be experienced (Derrida 1976, 65-66, 69; Harvey 1986, 121; Derrida 1973, 143; Heidegger 2002a, 14-15). As Derrida furthermore notes in On the Name regarding khora in Plato's Timaeus, this is a site "where the law of the proper no longer has any meaning" (Derrida 1995c, 105). In binding itself, the gift puts a supplement or substitute in the place of that which the structure inhibits or forbids (Derrida 1987, 393). It is nonetheless the only way in which the gift can appear or show itself as gift.

\section{The gift, time and law}

The above account is, as noted in the introduction, and as the discussion should have indicated, relevant not only in thinking the origin of law, but also of legal decisionmaking or interpretation. Derrida's analysis of the gift raises questions concerning the traditional model of decision-making in terms of which a collective subject identical to itself simply re-appropriates its identity through the decision (Derrida 1992a, 10-11). This model of decision-making can most clearly be seen in the recent debates in some jurisdictions concerning the common good as the primary function of law, whether viewed communally, nationally, regionally or internationally. ${ }^{25}$ It is nonetheless a characteristic of all legal discourses of self-legitimation, also of (legal) positivism, described by Heidegger (1991, IV 99) as "the real, the factual, which is ordered and arranged by...reason". The gift without exchange is also to be clearly distinguished from accounts of justice in liberal political theory, such as that of Rawls (1991). These accounts can be assessed in similar terms as Derrida's evaluation of Mauss's concluding remarks on the need for a return by contemporary society to the generous giving of ancient civilizations:

An expected, moderate, measured, or measurable gift, a gift proportionate to the benefit or to the effect one expects from it, a reasonable gift (that "good but moderate blend of reality and the ideal" that Mauss favored) would no longer be a gift; at most it would be a repayment of credit, the restricted economy of a differance, a calculable temporization or deferral (Derrida 1992a, 147).

${ }^{25}$ See Schuppert 2003, 215-260 for a summary. 
The founders of a state as well as legal decision-makers, as should be clear from the above discussion, are always already situated within the movement of différance and therefore also within the disseminal or thrown non-space and non-time of the gift. It is from this non-localizable point, beyond space and time, and therefore without meaning, without property, without law, without right, without reason, that responsibility in decision-making, a responsibility necessarily without limit and before memory must be thought (Derrida 1986a, 49a-53a; Derrida 2002a, 247-248). Responsibility, thought thus, would necessarily also require a negotiation with the possible and therefore a binding, which, as Derrida points out, "is immediately to supplement, to substitute, and therefore to represent, to replace, to put an Ersatz in the place of that which the structure inhibits or forbids" (Derrida 1987, 393; Derrida 2002a, 251). The re-appropriation or ex-appropriation which therefore necessarily follows upon such thrown-ness nevertheless cannot in the case of law be absolutely stabilized in the form of a collective subject. As Derrida (1995a, 270) puts it:

The subject assumes presence, that is to say sub-stance, stasis, stance. Not to be able to stabilize itself absolutely would mean to be able only to be stabilizing itself: relative stabilization of what remains unstable, or rather non-stable. Exappropriation no longer closes itself; it never totalizes itself.

This is why, in Force of Law, Derrida insists that there is the possibility of 'general strike', or what we could refer to here as 'the gift', in every interpretive reading (Derrida 2002a, 271). A written text such as a constitution opens itself to such a reading, as such a text, like the gift, does not return to the author. This is because a constitution ultimately amounts to a gift, in a similar way as does Mauss's The Gift, Heidegger's On Time and Being, the fragment from Madame de Maintenon (the morganatic wife of Louis XIV) and Baudelaire's Counterfeit Money, the gift-giving character of which Derrida explores in Given Time. This gift-characteristic of a constitution is of course not the result of the intentions of its authors, but because of the gift 'itself' which as we saw sets law in motion through the giving of time and Being (Derrida 1992a, 101). The gift, because of the stricture of différance, inevitably forms a part of the structure of every text. ${ }^{26}$

The possibility of the impossible gift in every interpretive reading entails also the 'right', granted by the gift, to suspend all norms of reading which ultimately also stand in the service of the preservation of law (Derrida 2002a, 271, 272). Constitutional interpretation cannot therefore, thought rigorously, consist simply of calculation or the application of norms of reading in an attempt to find, establish or create meaning. Set in motion by the gift, it should, it must affirm the gift. A legal reading affirming the gift has to defy the circularity of economic exchange; it has to involve a certain madness which 'allows' itself to be 'taken' by the gift. ${ }^{27}$ At the same time, because of the inevitable calculation and re-appropriation which is provoked by the unbearable demand of the gift; because of the necessity therefore of time

\footnotetext{
${ }^{26}$ See also Horner 2001, 202.

${ }^{27}$ See also Derrida 2002a, 255, 252; Derrida 1995d, 95.
} 
becoming space and space becoming time, constitutional reading also requires the taking account of or negotiation with law and rules (Derrida 1992a, 142; Derrida 2002a, 252). The gift, as we saw, inevitably erases, effaces itself in this negotiation and thus in the giving, so that we can never say, 'this is/was a gift or a just decision'. ${ }^{28}$ A thinking of the gift and its relation to the establishment of meaning nevertheless could allow us to think with Derrida in a different, or perhaps rather differantial way and therefore without falling into relativism, about issues of constitutional interpretation such as the death penalty (Derrida and Roudinesco 2004, 139-165), immigration/citizenship (Derrida and Dufourmantelle 2000, Derrida 1997), stem cell research (Derrida 2005b, 141-159), the notion of the family (Derrida and Roudinesco 2004, 33-46), man's relation to 'animals' (Derrida 2008), terrorism (Derrida 2003), the punishment of 'criminals' (Derrida and Roudinesco 2004, 139-196), dealing with 'rogue' states (Derrida 2005b), addressing poverty (Derrida 1995d, 85-86; Derrida 1992a, 134-145), the concepts of equality and freedom (Derrida 2005b, 19-62; Derrida and Roudinesco 2004, 47-61), the idea of self-government, and the issue of the sovereignty of the nation-state (Derrida 2005b). Without this thinking of the gift the meaning-giving subject would be forever simply caught in the circle of economic exchange.

Acknowledgement: The author would like to acknowledge the generous funding provided for the research by the Alexander von Humboldt Foundation and the South African National Research Foundation.

\section{References}

1. Abraham, Nicholas, and Maria Torok. 1994. The Shell and the Kernell: Renewals of Psychoanalysis. Volume I (trans: Nicholas Rand). Chicago and London: University of Chicago Press.

2. Ackerman, Bruce. 2007. The Living Constitution. Harvard Law Review. 120: 1737-1812.

3. Barnard, Jaco. 2006. Death, Mourning and Melancholia in Post-Modern Contract - A Call for (Re)establishing Contract's Connection with the Ethical. Stellenbosch Law Review. 17: 386-411.

4. Bennington, Geoffrey and Jacques Derrida. 1993. Derridabase/Circumfession. Chicago and London: University of Chicago Press.

5. Bischof, Sascha. 2004. Gerechtigkeit - Verantwortung - Gastfreundschaft: Ethik-Ansätze nach Jacques Derrida. Freiburg, Schweiz und Freiburg, Wien: Academic Press Fribourg und Verlag Herder.

6. Cornell, Drucilla. 1992. The Philosophy of the Limit. New York: Routledge.

7. Derrida, Jacques. 1973. Speech and Phenomena and Other Essays on Husserl's Theory of Signs (trans: David B. Allison). Evanston: Northwestern University Press.

8. Derrida, Jacques. 1976. Of Grammatology (trans: Gayatri Chakravorty Spivak). Baltimore and London: The John Hopkins University Press.

\footnotetext{
${ }^{28}$ See also Derrida 2002a, 251.
} 
9. Derrida, Jacques. 1979. Spurs: Nietzsche’s Styles (trans: Barbara Harlow). Chicago and London: University of Chicago Press.

10. Derrida, Jacques. 1982. Margins of Philosophy (trans Alan Bass). Chicago: University of Chicago Press.

11. Derrida, Jacques. 1986a. Glas (trans: John P. Leavey, JR., and Richard Rand). Lincoln and London: University of Nebraska Press.

12. Derrida, Jacques. 1986b. Foreword: Fors: The Anglish Words of Nicholas Abraham and Maria Torok (trans Barbara Johnson). In The Wolf Man's Magic Word: A Cryptonomy, Nicolas Abraham and Maria Torok, xi-xlviii. Minneapolis: University of Minnesota Press.

13. Derrida, Jacques. 1987. The Post Card: From Socrates to Freud and Beyond (trans: Alan Bass). Chicago and London: The University of Chicago Press.

14. Derrida, Jacques. 1988. The Ear of the Other, ed Christie McDonald (trans: Peggy Kamuf and Avital Ronell). Lincoln: University of Nebraska Press.

15. Derrida, Jacques. 1989a. Memoires for Paul de Man (trans: Cecile Lindsay, Jonathan Culler, Eduardo Cadava and Peggy Kamuf). New York: Columbia University Press

16. Derrida, Jacques. 1989b. Of Spirit: Heidegger and the Question (trans: Geoffrey Bennington and Rachel Bowlby). Chicago and London: University of Chicago Press.

17. Derrida, Jacques. 1991. A Derrida Reader: Between the Blinds, ed Peggy Kamuf. New York: Columbia University Press.

18. Derrida, Jacques. 1992a. Given Time: I. Counterfeit Money. Chicago and London: University of Chicago Press.

19. Derrida, Jacques. 1992b. Acts of Literature, ed Derek Attridge. New York and London: Routledge.

20.Derrida, Jacques. 1992c. The Other Heading: Reflections on Today's Europe (trans: Pascale-Anne Brault and Michael B. Naas). Bloomington and Indianapolis: Indiana University Press.

21. Derrida, Jacques. 1993a. Aporias (trans: Thomas Dutoit). Stanford, California: Stanford University Press.

22. Derrida, Jacques. 1993b. Heidegger's Ear: Philopolemology (Geschlecht IV) (trans: John P. Leavey, Jr.). In Reading Heidegger: Commemorations, ed Johan Sallis, 136-159. Bloomington and Indianapolis: Indiana University Press.

23. Derrida, Jacques. 1994. Specters of Marx: The State of Debt, the Work of Mourning, and The New International (trans: Peggy Kamuf). New York and London: Routledge.

24. Derrida, Jacques. 1995a. Points...Interviews, 1974-1994, ed Elisabeth Weber (trans: Peggy Kamuf et al). Stanford: Stanford University Press.

25. Derrida, Jacques. 1995b. Archive Fever: A Freudian Impression (trans: Eric Prenowitz). Chicago and London: The University of Chicago Press.

26. Derrida, Jacques 1995c. On the Name, ed Thomas Dutoit (trans: David Wood, John P. Leavey, Jr., and Ian McLeod). Stanford, California: Stanford University Press. 
27. Derrida, Jacques. 1995d. The Gift of Death (trans: David Wills). Chicago and London: University of Chicago Press.

28. Derrida, Jacques. 1997. Politics of Friendship (trans: George Collins). London and New York: Verso.

29. Derrida, Jacques and John D. Caputo. 1997. Deconstruction in a Nutshell: A Conversation with Jacques Derrida. New York: Fordham University Press.

30.Derrida, Jacques. 1998a. Faith and Knowledge: the Two Sources of 'Religion' at the Limits of Reason Alone (trans: Samuel Weber). In Religion, eds Jacques Derrida and Gianni Vattimo, 1-78. Stanford: Stanford University Press.

31. Derrida, Jacques. 1998b. Resistances of Psychoanalysis (trans: Peggy Kamuf, Pascale-Anne Brault, and Michael Naas). Stanford, California: Stanford University Press.

32. Derrida, Jacques. 1999a. Adieu: To Emmanuel Levinas (trans: Pascale-Anne Brault and Michael Naas). Stanford, California: Stanford University Press.

33. Derrida, Jacques. 1999b. Marx \& Sons. In Ghostly Demarcations: A Symposium on Jacques Derrida's Specters of Marx, ed Michael Sprinker, 213269, London and New York: Verso.

34. Derrida, Jacques and Anne Dufourmantelle. 2000. Of Hospitality (trans: Rachel Bowlby). Stanford, California: Stanford University Press.

35. Derrida, Jacques. 2001a. The Work of Mourning, eds Pascale-Anne Brault and Michael Naas. Chicago and London: University of Chicago Press.

36. Derrida, Jacques. 2001b. Writing and Difference (trans: Alan Bass). London and New York: Routledge.

37. Derrida, Jacques. 2002a. Acts of Religion, ed Gil Anidjar. New York and London: Routledge.

38. Derrida, Jacques. 2002b. Negotiations: Interventions and Interviews 19712001, ed and trans Elizabeth Rottenberg. Stanford: Stanford University Press.

39. Derrida, Jacques. 2002c. Positions (trans: Alan Bass). London and New York: Continuum.

40.Derrida, Jacques. 2003. Autoimmunity: Real and Symbolic Suicides: A Dialogue with Jacques Derrida. In Borradori, Giovanna. Philosophy in a Time of Terror: Dialogues with Jürgen Habermas and Jacques Derrida, 85-136.

41. Derrida, Jacques, and Roudinesco, Elisabeth. 2004. For What Tomorrow...A Dialogue (trans: Jeff Fort). Stanford: Stanford University Press.

42. Derrida, Jacques. 2005a. Women in the Beehive: A Seminar with Jacques Derrida. Differences: A Journal of Feminist Cultural Studies. 16: 139-157.

43. Derrida, Jacques. 2005b. Rogues: Two Essays on Reason (trans: PascaleAnne Brault and Michael Naas). Stanford: Stanford University Press.

44. Derrida, Jacques. 2007. Psyche: Inventions of the Other. Volume 1, eds Peggy Kamuf and Elizabeth Rottenberg. Stanford: Stanford University Press.

45. Derrida, Jacques. 2008. The Animal that Therefore I Am (trans: David Wills). New York: Fordham University Press.

46. Douzinas, Costas and Ronnie Warrington. 1994. Justice Miscarried. : Ethics and Aesthetics in Law. New York: Harvester Wheatsheaf. 
47. Douzinas, Costas. 2007. Human Rights and Empire: The Political Philosophy of Cosmopolitanism. London and New York: Routledge-Cavendish.

48. Fitzpatrick, Peter. 2001. Modernism and the Grounds of Law. Cambridge: Cambridge University Press.

49. Freud, Sigmund. 2001a. The Standard Edition of the Complete Psychological Works of Sigmund Freud. Volume VII (1901-1905). London: Vintage.

50. Freud, Sigmund. 2001b. The Standard Edition of the Complete Psychological Works of Sigmund Freud. Volume XVIII (1920-1922). London: Vintage.

51. Freud, Sigmund. 2001c. The Standard Edition of the Complete Psychological Works of Sigmund Freud. Volume XIX (1923-1925). London: Vintage.

52. Freud, Sigmund. 2001d. The Standard Edition of the Complete Psychological Works of Sigmund Freud. Volume XXI (1927-1931). London: Vintage.

53. Gasché, Rodolphe. 1994. Inventions of Difference: On Jacques Derrida. Cambridge, Massachusetts and London, England. Harvard University Press.

54. Harvey, Irene E. 1986. Derrida and the Economy of Différance. Bloomington: Indiana University Press.

55. Heidegger, Martin. 1962. Being and Time (trans: John Macquarrie and Edward Robison). San Francisco: Harper \& Row.

56. Heidegger, Martin. 1977. The Question Concerning Technology and Other Essays (trans: William Lovitt). New York: Harper Perennial.

57. Heidegger, Martin. 1984a. Early Greek Thinking: The Dawn of Western Philosophy (trans: David Farrell Krell and Frank A. Capuzzi). New York: Harper \& Row Publishers.

58. Heidegger, Martin. 1984b. The Metaphysical Foundations of Logic (trans: Michael Heim). Bloomington and Indianapolis: Indiana University Press.

59. Heidegger, Martin. 1991. Nietzsche. Volumes I to IV (trans: David Farrell Krell). San Francisco: Harper \& Row.

6o.Heidegger, Martin. 1993. Basic Writings, ed David Farrell Krell. New York: HarperCollins Publishers.

61. Heidegger, Martin. 2000. Introduction to Metaphysics (trans: Gregory Fried and Richard Polt). New Haven and London: Yale University Press.

62. Heidegger, Martin. 2002a. On Time and Being (trans: Joan Stambaugh). Chicago and London: University of Chicago Press.

63. Heidegger, Martin. 2002b. Identity and Difference (trans: Joan Stambaugh). Chicago and London: University of Chicago Press.

64. Heidegger, Martin. 2005. The Essence of Human Freedom: An Introduction to Philosophy (trans: Ted Sadler). London: Continuum.

65. Horner, Robyn. 2001. Rethinking God as Gift: Marion, Derrida, and the Limits of Phenomenology. New York: Fordham University Press.

66. Hyppolite, Jean. 1974. Genesis and Structure of Hegel's Phenomenology of Spirit (trans: Samuel Cherniak and John Heckman). Evanston: Northwestern University Press.

67. Kamuf, Peggy. 2001. Derrida and Gender: The Other Sexual Difference. In Jacques Derrida and the Humanities: A Critical Reader, ed Tom Cohen. Cambridge: Cambridge University Press. 
68. Kockelmans, Joseph J. 1989. Heidegger's 'Being and Time': The Analytic of Dasein as Fundamental Ontology. Washington, D.C: Center for Advanced Research in Phenomenology and University Press of America.

69. Krell, David Farrell. 2000. The Purest of Bastards: Works of Mourning, Art, and Affirmation in the Thought of Jacques Derrida. Pennsylvania: Pennsylvania State University Press.

70. Marrati. Paola Marrati. 2005. Genesis and Trace: Derrida Reading Husserl and Heidegger. Stanford, California: Stanford University Press.

71. Mauss, Marcel. 1990. The Gift: The Form and Reason for Exchange in Archaic Societies (trans: W.D. Halls). London and New York: Routledge.

72. Minkkinen, Panu. 1999. Thinking Without Desire: A First Philosophy of Law. Oxford: Hart Publishing.

73. Rawls, John. 1999. A Theory of Justice. Revised Edition. Cambridge, Massachusetts: Harvard University Press.

74. Rubenfeld, Jed. 1998. Legitimacy and Interpretation. In Constitutionalism: Philosophical Foundations, ed Larry Alexander, 194-234. Cambridge: Cambridge University Press.

75. Rubenfeld, Jed. 2001. Freedom and Time: A Theory of Constitutional SelfGovernment. New Haven and London: Yale University Press.

76. Schuppert, Gunnar Folke. 2003. Staatswissenschaft. Baden-Baden: Nomos Verlagsgesellschaft.

77. Taminiaux, Jacques. 1994. Philosophy of Existence I: Heidegger. In Routledge History of Philosophy Volume VIII: Twentieth-Century Continental Philosophy, ed Richard Kearney, 38-73. London and New York: Routledge.

78. Sheehan, Thomas. 1998. Heidegger, Martin (1889-1976). In Routledge Encyclopedia of Philosophy, ed Edward Craig, 307-323. London and New York: Routledge.

79. Van der Walt, Johan. 2005. Law and Sacrifice: Towards a Post-Apartheid Theory of Law. London and Johannesburg: Birkbeck Law Press and Wits University Press. 